Asian J Agric \& Biol. 2021(4).

\title{
Comparison of the physical spray efficacy between unmanned helicopter and motorized knapsack sprayer in Thai paddy field
}

\author{
Pruetthichat Punyawattoe ${ }^{1 *}$, Woravit Sutjaritthammajariyangkun ${ }^{1}$, Supangkana Thirawut ${ }^{1}$, Nalina \\ Chaiyasing1, Suchada Supornsin ${ }^{1}$, Sonthaya Sampaothong², Tomohiro Nagura ${ }^{3}$ \\ ${ }^{1}$ Pesticide Application Research Section, Entomology and Zoology Group, Plant Protection Research and Development \\ Office, Department of Agriculture, Bangkok, Thailand \\ ${ }^{2}$ Department of Agricultural Extension and Communication, Faculty of Agriculture at Kamphaeng Saen, Kasetsart \\ University, Kamphaeng Saen Campus, Nakhon Pathom, Thailand \\ ${ }^{3}$ Siam Yamaha Motor Robotics Co., Ltd., Thailand
}

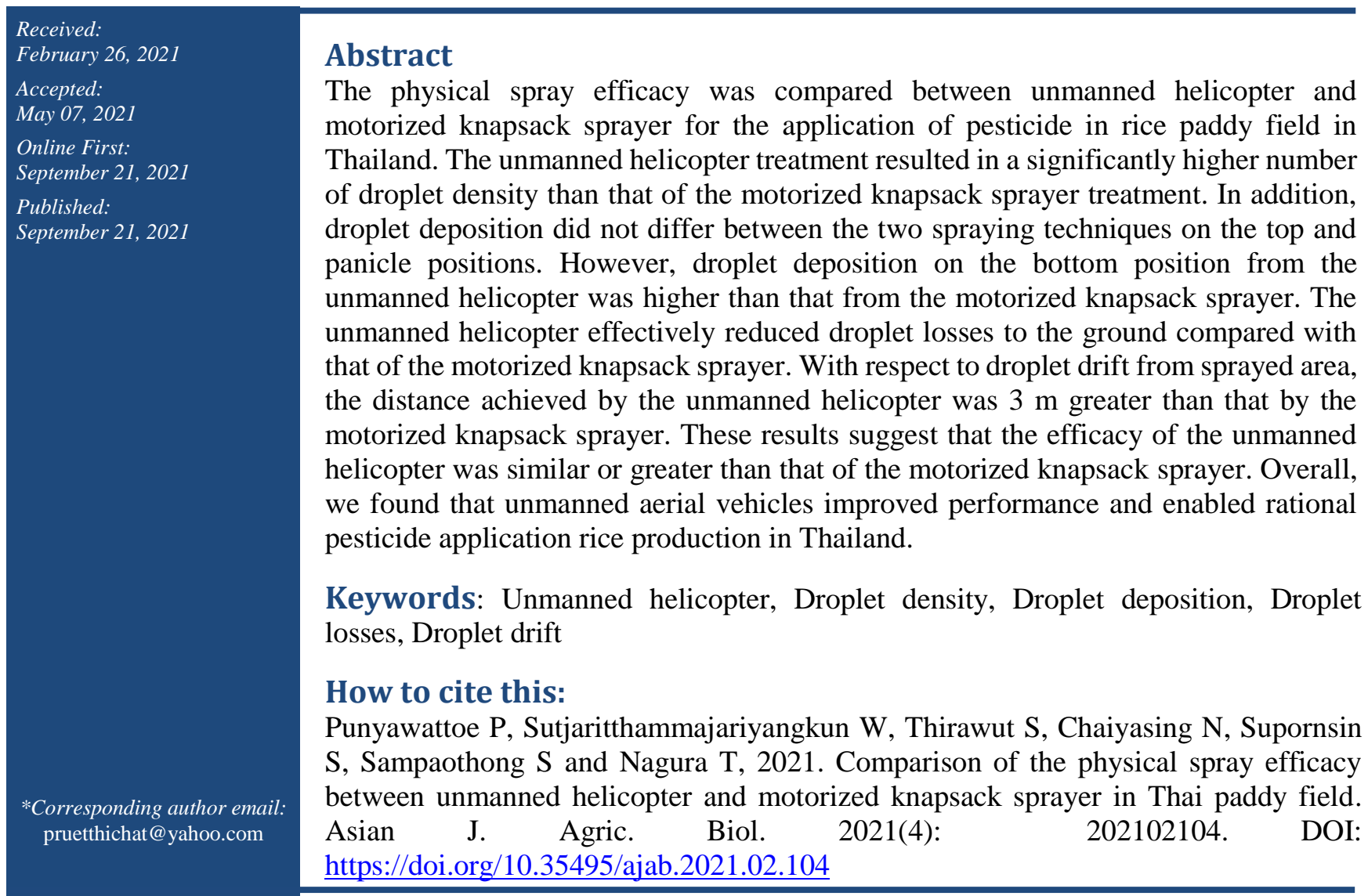

This is an Open Access article distributed under the terms of the Creative Commons Attribution 3.0 License. (https://creativecommons.org/licenses/by/3.0), which permits unrestricted use, distribution, and reproduction in any medium, provided the original work is properly cited.

\section{Introduction}

Rice is an important crop that plays a major role in the economy of Thailand (Office of Agricultural Economics, 2018). However, approximately 50 different species of pests have been reported to damage rice crops in Thailand (Rice Department, 2018). Typically, insecticides to control these pests are applied at a high spray volume using a spray lance fitted onto a motorized hydraulic knapsack sprayer by farmers in Thailand (Pojananuwong et al., 1999 \& 2001). The efficacy of this control measure depends on the 
operator's skill and efforts. In addition, studies have reported that farmers' spraying techniques may pose a safety issue regardless of personal protective equipment and appropriate spray application techniques (Hughes et al., 2008; Nuyttens et al., 2009). The number of reported cases of pesticide poisoning among farmers in Thailand has considerably increased from 2010 to 2017 (Ministry of Public Health, 2018). Moreover, the estimates of operator exposure have been reported for several classes of pesticides and from diverse types of application equipment (Hughes et al., 2008; Nuyttens et al., 2009). These figures reveal the necessity of improved site-specific occupational hygiene. Importantly, the non-uniformity of dermal exposure from different kinds of spray application techniques and spray volumes has been reported (Thongsakul et al., 1999; Machera et al., 2002).

All the aforementioned studies have raised concerns about the need to improve spray application techniques. At present, the safety of operators, price of insecticides, lack of laborers, and increasing cost of operating in paddy fields have to be improved on spray application techniques to achieve better results (Wechakit et al., 2009).

In recent years, unmanned aerial vehicles (UAVs) has become an interesting alternative application method in several countries in Asia (Xue et al., 2016). At present, UAV's are effective sprayers and play an important role in controlling all sorts of pests, especially in rice (Xue et al., 2008 and Qin et al., 2018).

In Thailand, some agricultural chemical operators, farmers, and spray service providers are using UAVs in paddy fields. Most UAVs, however, are imported but they were never tested for efficacy. Hence, basic information on good UAVs application practice has to be explored. Therefore, in this study, the number of droplet density on target areas, droplet deposition on rice canopy, droplet losses to the ground, and droplet drift from the sprayed area resulting from unmanned helicopter in paddy field were compared with those from motorized knapsack sprayer to optimize UAVs application techniques in Thailand.

\section{Material and Methods}

\section{Spray application techniques}

Four application treatments were designed for testing (Table 1). The first two applications utilized the FAZER helicopter (Yamaha Corporation, Hamamatsu, Japan) with two fan-type nozzles (XR 110025; Spraying Systems Co., Ltd., Glendale Heights, IL,
USA) at a rate of 8 or $16 \mathrm{~L} / \mathrm{ha}$, designated as unmanned helicopter 1 (UH1) and UH2, respectively. The other two applications utilized a motorized knapsack sprayer (Maruyama model MS 073D) with a tank capacity of 25 L (Maruyama Co., Ltd., Tokyo, Japan) and an attached spray lance that operated at a rate of 250 or 375 L/ha, designated as motorized knapsack 1 (MK1) and MK2, respectively.

Table-1. Application parameters for pesticide spraying experiments

\begin{tabular}{|c|c|c|c|c|}
\hline $\begin{array}{l}\text { Application } \\
\text { parameters }\end{array}$ & \multicolumn{2}{|c|}{$\begin{array}{c}\text { Unmanned helicopter } \\
\text { (UH; FAZER) }\end{array}$} & \multicolumn{2}{|c|}{$\begin{array}{c}\text { Motorized knapsack } \\
\text { sprayer (MK; MS 073D) }\end{array}$} \\
\hline & UH1 & UH2 & MK1 & MK2 \\
\hline Rotor & Single & Single & - & - \\
\hline Nozzle type & $\begin{array}{c}\text { Fan type } \\
(\mathrm{XR} 110025)\end{array}$ & $\begin{array}{c}\text { Fan type } \\
\text { (XR110025) }\end{array}$ & $\begin{array}{c}\text { Adjustable } \\
\text { cone } \\
\text { Orifice } \\
\text { diameter at } 1.2 \\
\text { mm installed } \\
\text { with spray } \\
\text { lance }\end{array}$ & $\begin{array}{c}\text { Adjustable } \\
\text { cone Orifice } \\
\text { diameter at } \\
1.2 \mathrm{~mm} \\
\text { installed } \\
\text { with spray } \\
\text { lance }\end{array}$ \\
\hline VMD $(\mu \mathrm{m})$ & 160 & 160 & 212 & 212 \\
\hline $\begin{array}{l}\text { Number of } \\
\text { nozzles }\end{array}$ & 2 & 2 & 1 & 1 \\
\hline Pressure (bar) & 3.3 & 3.3 & 5 & 5 \\
\hline $\begin{array}{l}\text { Spray output } \\
(\mathrm{ml} / \mathrm{min})\end{array}$ & 1000 & 1000 & 2100 & 2100 \\
\hline Spray angle & $0^{\mathbf{o}}$; vertical & $0^{\mathbf{o}}$; vertical & $45^{\circ}$; horizontal & $\begin{array}{c}45^{\circ} ; \\
\text { horizontal }\end{array}$ \\
\hline $\begin{array}{l}\text { Swath width } \\
(\mathrm{m})\end{array}$ & 8 & 8 & 4 & 4 \\
\hline $\begin{array}{l}\text { Working } \\
\text { width }(\mathrm{m})\end{array}$ & \multicolumn{2}{|c|}{$\begin{array}{l}24 \mathrm{~m} \text { in total; divided into } \\
\text { three sections of } 8 \mathrm{~m} \text { each }\end{array}$} & \multicolumn{2}{|c|}{$\begin{array}{c}24 \mathrm{~m} \text { in total; divided into } \\
\text { six } \\
\text { sections of } 4 \mathrm{~m} \text { each }\end{array}$} \\
\hline $\begin{array}{l}\text { Working } \\
\text { height }(\mathrm{m})\end{array}$ & 3 & 3 & 0.5 & 0.5 \\
\hline $\begin{array}{l}\text { Travelling } \\
\text { speed } \\
(\mathrm{m} / \mathrm{min})\end{array}$ & 178 & 89 & 21 & 14 \\
\hline $\begin{array}{l}\text { Tank capacity } \\
\text { (L) }\end{array}$ & 24 & 24 & 25 & 25 \\
\hline $\begin{array}{l}\text { Application } \\
\text { rate } \\
\text { (L/ha) } \\
\end{array}$ & 8 & 16 & 250 & 375 \\
\hline $\begin{array}{l}\text { Application } \\
\text { technique }\end{array}$ & $\begin{array}{c}\text { Very low } \\
\text { volume } \\
\text { application }\end{array}$ & $\begin{array}{c}\text { Very low } \\
\text { volume } \\
\text { application }\end{array}$ & $\begin{array}{c}\text { Medium } \\
\text { volume } \\
\text { application }\end{array}$ & $\begin{array}{c}\text { Medium } \\
\text { volume } \\
\text { application }\end{array}$ \\
\hline
\end{tabular}

Experiment site data collection, processing, and analysis

Field experiments were conducted in Suphanburi, Thailand. The experiments were performed using a randomized complete block design, with four spray application techniques and five replicates per technique. Each plot size had an area of $50 \mathrm{~m} \times 24 \mathrm{~m}$. Field studies were conducted on rice at 45,70 , and 90 days after sowing (represented the most frequency to spray insecticide and fungicide in the field) to compare the number of droplet density on target areas, droplet 
deposition on rice canopy, droplet losses to the ground, and droplet drift from sprayed area under working conditions.

In this experiment, the results were expected to vary both across the swath width, spray direction and the meteorological conditions. Thus, sampling positions in this experiment were selected to account for this factor as much as possible. To avoid cross-contamination between plots, the sampling site was located $20 \mathrm{~m}$ from the edge of each treatment plot (Xinyu et al., 2014 and Wang et al., 2017).

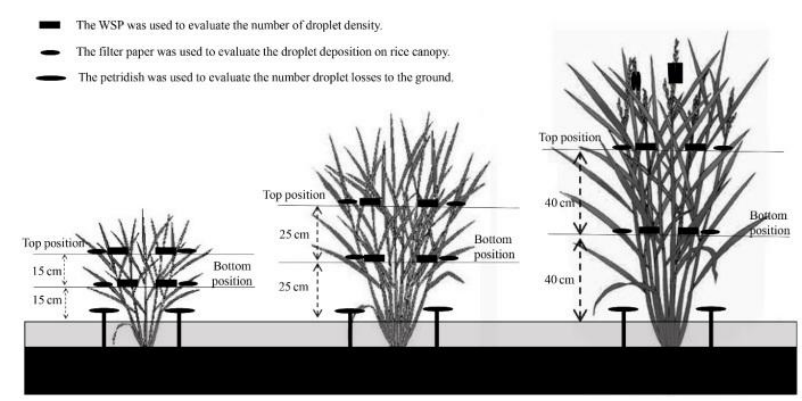

Figure-1. Sampling collectors for density deposition and losses to the ground

\section{Environment monitoring}

The ambient temperature and relative humidity at 1,2, and $3.0 \mathrm{~m}$ above the target areas were recorded using the Extech 45160 Humidity, Temperature, and Airflow Meter and the Extech 42270 data logger (Extech Instruments, Waltham, MA, USA).

\section{Sampling methods}

Fig. 1 shows how the sampling collectors and deposition, and losses to the ground were arranged in the sprayed area. The sample collectors for measuring the number of droplet density on target areas consisted of a $25 \mathrm{~mm} \times 75 \mathrm{~mm}$ of water-sensitive paper (WSP). It was used to evaluate the number of droplet density. The WSPs were adjusted to assist in positioning the papers at a height equivalent to the top and bottom positions of the rice canopy at the tillering and heading stages and fixed vertically on rice panicle at the flowering stage (upwind and downwind positions). The interval of sampling points was $2 \mathrm{~m}$ in the rice canopy according to Fig. 1.

After spraying, naturally dried WSPs were placed in plastic bags with labels indicating the treatment of spraying. The bags were then tightly sealed and kept in a UV-proof container, to protect the dye and taken to the lab; the number of droplet density on target areas was computed using the image processing software Deposit Scan. Droplet deposition, droplet losses to the ground and droplet drift were determined using the colorimetric method with a tracer dye. Tartrazine, at a concentration of $3 \%$, was chosen for the present experiment, because of its safety, high accuracy and sensitivity with a significant reduce operation time and cost. In addition, it easily can be extracted from Petri dishes and plant cellulose and stable under various light and temperature conditions (Wicke et al., 1999 and Pergher, 2001). To determine droplet deposition on rice canopy, the sampling collector consisted of a filter paper $(\phi=70 \mathrm{~mm})$. Before spraying, a stapler was used to attach the filter papers to rice leaves and panicles in the rice canopy. The filter papers were placed as shown in Figure 1. To determine spray losses to the ground, Petri dishes attached to a metal spike were placed 0.05 $\mathrm{m}$ above ground level. The interval of sampling points was $2 \mathrm{~m}$ in the sprayed area as shown in Fig. 1.

Droplet drift from sprayed area was evaluated by setting up sampling lines downwind where Petri dishes of $90 \mathrm{~mm}$ diameter were attached to a metal spike were arranged 1-m apart at the top of the rice canopy up to $20 \mathrm{~m}$ apart from the sprayed area (Fig. 2). The collectors were taken from the field $30 \mathrm{~min}$ after finishing the application and washed using distilled water. The washing solution for each position was stored for further analysis. In the laboratory, the samples were analyzed using a colorimetric method to determine tartrazine content in the washing solutions. For making the tracer dye spray more accuracy, after UH took off and was hovering $20 \mathrm{~m}$ from the sprayed area and stopped spraying $10 \mathrm{~m}$ away. The flight height (above the crop surface) was $3 \mathrm{~m}$.

\section{Detection of tracer dye}

In all experiments, the samples were analyzed by colorimetry (Jenway model 6051; Spectronic Camspec Ltd., Leeds, UK) to measure the specific absorption of tartrazine at $470 \mathrm{~nm}$. After spraying, the samples were removed carefully with a pair of forceps and each sample was placed in a zip-lock bag and labeled. The samples were spiked in the laboratory with a standard calibration solution. In spite of the high stability of tartrazine, the samples were stored and transported under cool and dark conditions. The tracer was rinsed off the patches using $10 \mathrm{~mL}$ of demineralized water in disposable Petri dishes. For analysis of sample, a colorimeter with a micro-plastic cuvette of capacity 3 $\mathrm{mL}$ was used. The readings are expressed in $\mu \mathrm{g} / \mathrm{L}$. The amount of tracer contained in the sample was 
calculated for each measurement target. An allowance was made for various correction factors, such as dilution, measurement range and the volume of the absorbent liquid. The results of droplet deposition are expressed in $\mu \mathrm{g} / \mathrm{unit}$ area.

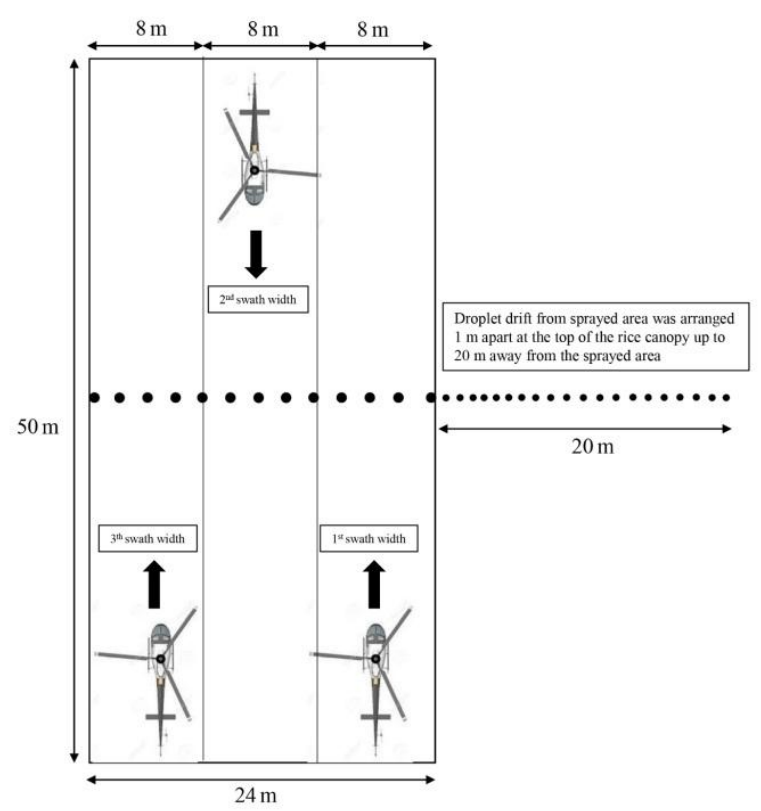

Figure-2. Sampling collectors for droplet drift

\section{Statistical analysis}

Before the analysis of significant difference, the number of droplet density on target areas, total droplet deposition, and losses to the ground, were transformed by using $\log (\mathrm{x}+1)$. Significant differences were determined using an analysis of variance (ANOVA) and Tukey's test at a significance level of $95 \%$ with SPSS v. 22.0 (SPSS, Inc., IBM, Chicago, IL, USA).

\section{Results and Discussion}

\section{Environment during field performance}

The average wind speed, ambient temperature and relative humidity of the experiment are shown in Table 2.

\section{Number of droplet density on target areas, the total} droplet deposition and losses to the ground

The number of droplet density on target areas from both unmanned helicopter treatments was 46.8-92.6 droplets $/ \mathrm{cm}^{2}$, higher than that of the motorized knapsack sprayer treatments $\left(29.8-78.6\right.$ droplets $\left./ \mathrm{cm}^{2}\right)$
(Table 3). The spraying technique had a major effect on the number of droplet density. Previous studies have reported that effective treatments for insecticide or preemergence herbicide applications to control insect pests and weeds require at least $20-30$ droplets $/ \mathrm{cm}^{2}$, for contact post-emergence herbicide applications require at least 30-40 droplets $/ \mathrm{cm}^{2}$, and for fungicide applications require at least $50-70$ droplets $/ \mathrm{cm}^{2}$, respectively (Matthews et al., 2014). In addition, Ebert et al. (1999) reported that the number of spray deposits only needs to reach a certain threshold to achieve sufficient control efficacy. Based on these reports, the number of deposits from both unmanned helicopter treatment was sufficient for all types of pesticide.

Table-2. Wind speed, ambient temperature, and relative humidity averaged over a minute during field performance

\begin{tabular}{|c|c|c|c|c|c|c|c|c|c|}
\hline Parameter & \multicolumn{3}{|c|}{$\begin{array}{c}\text { Wind speed } \\
(\mathbf{m} / \mathbf{s})\end{array}$} & \multicolumn{3}{c|}{$\begin{array}{c}\text { Ambient } \\
\text { temperature } \\
\left({ }^{\circ} \mathbf{C}\right)\end{array}$} & \multicolumn{3}{c|}{$\begin{array}{c}\text { Relative } \\
\text { humidity (\%) }\end{array}$} \\
\hline $\begin{array}{c}\text { Height of } \\
\text { measurement (m) }\end{array}$ & $\mathbf{1}$ & $\mathbf{2}$ & $\mathbf{3}$ & $\mathbf{1}$ & $\mathbf{2}$ & $\mathbf{3}$ & $\mathbf{1}$ & $\mathbf{2}$ & $\mathbf{3}$ \\
\hline $\begin{array}{c}\text { Under field } \\
\text { conditions }\end{array}$ & $\begin{array}{c}0.1 \\
\pm\end{array}$ & $\begin{array}{c}0.2 \\
\pm\end{array}$ & $\begin{array}{c}0.2 \\
\pm\end{array}$ & $\begin{array}{c}22.3 \\
\pm\end{array}$ & $\begin{array}{c}23.8 \\
\pm\end{array}$ & $\begin{array}{c}24.1 \\
\pm\end{array}$ & $\begin{array}{c}80.2 \\
\pm\end{array}$ & $\begin{array}{c}82.4 \\
\pm\end{array}$ & $\begin{array}{c}83.1 \\
\pm\end{array}$ \\
\hline
\end{tabular}

The total droplet deposition with the unmanned helicopters on the top position and panicle position was not significantly different from that of the motorized knapsack sprayers. Although UH2, MK1, and MK2 delivered a higher spray volume than that of UH1, the volume of dye deposition was not significantly different from that of $\mathrm{UH} 1$, which operated at the lowest spray volume of $8 \mathrm{~L} / \mathrm{ha}$.

On the contrary, the total deposition of the unmanned helicopters on the bottom position was significantly different from that of the motorized knapsack sprayers (Table 4). This result suggested that the air stream from downward direction below the rotors may increase droplet penetration when the unmanned helicopter is operated for very low volume spraying. In addition, the air stream generated by the rotor wings has perturbed the rice plants, as the droplets often penetrated into the canopy and reached to the target areas. Although the motorized knapsack sprayers delivered 90\% more spray volume than the unmanned helicopters, they did not produce significantly higher densities and deposits than that of the unmanned helicopters, which operated at lower spray volumes of 8 and $16 \mathrm{~L} / \mathrm{ha}$. 
Table-3. Mean \pm SE of the number of droplet density on target areas from the four spraying techniques

\begin{tabular}{|c|c|c|c|c|c|c|c|c|}
\hline \multirow[b]{3}{*}{ Treatment } & \multirow{3}{*}{$\begin{array}{c}\text { Spray } \\
\text { volume } \\
\text { (L/ha) }\end{array}$} & \multicolumn{7}{|c|}{ Mean \pm SE of the number of droplet density (droplets $\left./ \mathrm{cm}^{2}\right)$} \\
\hline & & \multicolumn{2}{|c|}{ Tillering stage } & \multicolumn{2}{|c|}{ Heading stage } & \multicolumn{3}{|c|}{ Flowering stage } \\
\hline & & $\begin{array}{c}\text { Top } \\
\text { position }\end{array}$ & $\begin{array}{c}\text { Bottom } \\
\text { position }\end{array}$ & $\begin{array}{c}\text { Top } \\
\text { position }\end{array}$ & $\begin{array}{c}\text { Bottom } \\
\text { position }\end{array}$ & $\begin{array}{c}\text { Top } \\
\text { position }\end{array}$ & $\begin{array}{c}\text { Bottom } \\
\text { position }\end{array}$ & $\begin{array}{c}\text { Panicle } \\
\text { position }\end{array}$ \\
\hline UH1 & 8 & $89.8 \pm 4.0$ & $74.0 \pm 4.8 \mathrm{a}$ & $90.2 \pm 5.1 \mathrm{a}$ & $59.4 \pm 3.4 \mathrm{a}$ & $92.4 \pm 3.4 \mathrm{a}$ & $50.8 \pm 2.4 \mathrm{a}$ & $91.8 \pm 4.7 \mathrm{ab}$ \\
\hline $\mathrm{UH} 2$ & 16 & $89.2 \pm 5.1$ & $72.6 \pm 3.1 \mathrm{a}$ & $92.6 \pm 5.2 \mathrm{a}$ & $58.2 \pm 4.0 \mathrm{a}$ & $93.2 \pm 4.1 \mathrm{a}$ & $51.6 \pm 2.9 \mathrm{a}$ & $93.4 \pm 5.0 \mathrm{a}$ \\
\hline MK1 & 250 & $77.8 \pm 3.6$ & $52.2 \pm 2.7 \mathrm{~b}$ & $73.0 \pm 4.3 \mathrm{~b}$ & $36.6 \pm 2.5 b$ & $73.2 \pm 3.0 \mathrm{~b}$ & $29.8 \pm 2.0 \mathrm{~b}$ & $75.2 \pm 3.9 \mathrm{~b}$ \\
\hline MK2 & 375 & $76.4 \pm 5.3$ & $52.4 \pm 4.2 \mathrm{~b}$ & $78.6 \pm 4.5 \mathrm{ab}$ & $39.6 \pm 3.0 \mathrm{~b}$ & $75.2 \pm 4.2 \mathrm{~b}$ & $31.0 \pm 1.7 \mathrm{~b}$ & $77.4 \pm 3.8 \mathrm{ab}$ \\
\hline $\mathrm{CV}(\%)$ & & 11.84 & 8.43 & 10.76 & 16.63 & 10.68 & 9.04 & 11.48 \\
\hline$F$ & & 2.48 & 26.27 & 5.39 & 11.14 & 7.30 & 53.18 & 4.78 \\
\hline$P$ & & 0.11 & $<0.01$ & 0.01 & $<0.01$ & $<0.01$ & $<0.01$ & 0.02 \\
\hline
\end{tabular}

Values followed by the same letter in the column do not differ statistically ( $p<0.05$; Tukey's Test). UH: unmanned helicopter, MK: motorized knapsack.

Table-4. Mean $\pm \mathrm{SE}$ of droplet deposition and losses to the ground from the four spraying techniques

\begin{tabular}{|c|c|c|c|c|c|c|c|c|c|c|c|}
\hline \multirow[b]{3}{*}{ Treatment } & \multirow[b]{3}{*}{$\begin{array}{l}\text { Spray } \\
\text { volume } \\
\text { (L/ha) }\end{array}$} & \multicolumn{10}{|c|}{ Mean $\pm \mathrm{SE}$ of droplet deposition and losses to the ground $\left(\mu \mathrm{g} / \mathrm{cm}^{2}\right)$} \\
\hline & & \multicolumn{3}{|c|}{ Tillering stage } & \multicolumn{3}{|c|}{ Heading stage } & \multicolumn{4}{|c|}{ Flowering stage } \\
\hline & & $\begin{array}{c}\text { Top } \\
\text { position }\end{array}$ & Bottom position & $\begin{array}{l}\text { Losses to } \\
\text { the } \\
\text { ground }\end{array}$ & $\begin{array}{c}\text { Top } \\
\text { position }\end{array}$ & $\begin{array}{c}\text { Bottom } \\
\text { position }\end{array}$ & \begin{tabular}{|l} 
Losses to \\
the \\
ground
\end{tabular} & $\begin{array}{c}\text { Top } \\
\text { position }\end{array}$ & $\begin{array}{l}\text { Bottom } \\
\text { position }\end{array}$ & $\begin{array}{l}\text { Panicle } \\
\text { position }\end{array}$ & $\begin{array}{l}\text { Losses to } \\
\text { the } \\
\text { ground }\end{array}$ \\
\hline UH1 & 8 & $1.36 \pm 0.04$ & $1.10 \pm 0.06 \mathrm{a}$ & $\begin{array}{c}0.68 \\
\pm 0.02 \mathrm{~b} \\
\end{array}$ & $\begin{array}{c}1.48 \\
\pm 0.04 \mathrm{a} \\
\end{array}$ & $\begin{array}{c}1.14 \\
\pm 0.07 \mathrm{a} \\
\end{array}$ & $\begin{array}{c}0.55 \\
\pm 0.03 \mathrm{~b} \\
\end{array}$ & $\begin{array}{c}0.94 \\
\pm 0.03 \\
\end{array}$ & $\begin{array}{c}0.74 \\
\pm 0.02 \mathrm{a} \\
\end{array}$ & $\begin{array}{c}1.06 \\
\pm 0.06 \\
\end{array}$ & $\begin{array}{c}0.37 \\
\pm 0.03 \mathrm{~b} \\
\end{array}$ \\
\hline $\mathrm{UH} 2$ & 16 & $1.40 \pm 0.04$ & $1.06 \pm 0.04 \mathrm{a}$ & $\begin{array}{c}0.72 \\
\pm 0.04 \mathrm{~b}\end{array}$ & $\begin{array}{c}1.40 \\
\pm 0.03 \mathrm{ab}\end{array}$ & $\begin{array}{c}1.17 \\
\pm 0.06 \mathrm{a}\end{array}$ & $\begin{array}{c}0.58 \\
\pm 0.02 \mathrm{~b}\end{array}$ & $\begin{array}{c}0.91 \\
\pm 0.04\end{array}$ & $\begin{array}{c}0.76 \\
\pm 0.03 \mathrm{a}\end{array}$ & $\begin{array}{c}1.04 \\
\pm 0.04\end{array}$ & $\begin{array}{c}0.45 \\
\pm 0.03 \mathrm{~b}\end{array}$ \\
\hline MK1 & 250 & $1.25 \pm 0.03$ & $0.84 \pm 0.04 \mathrm{~b}$ & $\begin{array}{c}1.10 \\
\pm 0.06 \mathrm{a}\end{array}$ & $\begin{array}{c}1.28 \\
\pm 0.05 \mathrm{~b}\end{array}$ & $\begin{array}{c}0.86 \\
\pm 0.05 \mathrm{~b}\end{array}$ & $\begin{array}{c}0.86 \\
\pm 0.03 \mathrm{a}\end{array}$ & $\begin{array}{c}0.79 \\
\pm 0.03\end{array}$ & $\begin{array}{c}0.53 \\
\pm 0.04 \mathrm{~b}\end{array}$ & $\begin{array}{c}1.10 \\
\pm 0.05\end{array}$ & $\begin{array}{c}0.60 \\
\pm 0.04 \mathrm{a}\end{array}$ \\
\hline MK2 & 375 & $1.29 \pm 0.04$ & $0.87 \pm 0.04 \mathrm{~b}$ & $\begin{array}{c}1.13 \\
\pm 0.04 \mathrm{a}\end{array}$ & $\begin{array}{c}1.33 \\
\pm 0.03 \mathrm{ab}\end{array}$ & $\begin{array}{c}0.94 \\
\pm 0.05 \mathrm{ab}\end{array}$ & $\begin{array}{c}0.94 \\
\pm 0.04 \mathrm{a}\end{array}$ & $\begin{array}{c}0.98 \\
\pm 0.06\end{array}$ & $\begin{array}{c}0.57 \\
\pm 0.02 \mathrm{~b}\end{array}$ & $\begin{array}{c}1.14 \\
\pm 0.05\end{array}$ & $\begin{array}{c}0.67 \\
\pm 0.05 \mathrm{a}\end{array}$ \\
\hline $\mathrm{CV}(\%)$ & & 7.09 & 9.13 & 9.51 & 7.22 & 13.68 & 7.11 & 13.52 & 9.84 & 9.95 & 10.03 \\
\hline$F$ & & 2.44 & 11.39 & 39.47 & 3.84 & 5.73 & 72.27 & 0.98 & 16.68 & 0.93 & 32.88 \\
\hline$P$ & & 0.11 & $<0.01$ & $<0.01$ & 0.03 & 0.01 & $<0.01$ & 0.43 & $<0.01$ & 0.45 & $<0.01$ \\
\hline
\end{tabular}

Values followed by the same letter in the column do not differ statistically ( $p<0.05$; Tukey's Test). UH: unmanned helicopter, MK: motorized knapsack.

In addition, most of the smaller droplets are free in the air, and more easily reach the lower canopy of the crop. Therefore, smaller droplets may have better penetration than larger droplets for the ground spraying equipment. This result agrees with Qin et al. (2018) and Wang et al. (2019) who found that the impact of UAV spraying on the distribution and deposition of droplets on canopy of wheat was quite significant especially during the late growing stages when the leaf area index was the largest, the droplets coverage by routine ground sprayer was distinctly lower than that realized by UAV.

The unmanned helicopter techniques showed relatively lower dye deposition and, correspondingly, the two motorized knapsack techniques MK1 and MK2 resulted in higher losses to the ground by more than $35 \%-39 \%, 32 \%-41 \%$, and $25 \%-44 \%$ on rice at the tillering, heading, and flowering stages, respectively (Table 3).
As reported in other studies, it is likely that high- and medium-volume sprayings lead to increased run-off (Sánchez-Hermosilla et al., 2012; Rincón et al., 2017 and Wang et al., 2019). Spraying with coarse droplet resulted in high losses to the ground inside the field when compared with that of spraying with fine droplet (Derksen et al., 2007). Our results showed a similar trend to that of the previous studies.

\section{Droplet drift deposition from sprayed area}

Throughout the experiment, the height of the unmanned helicopters was $3 \mathrm{~m}$ above the top of the crops, wind speed was less than $0.3 \mathrm{~m} / \mathrm{s}$, average ambient temperature was $24{ }^{\circ} \mathrm{C}$, and average relative humidity was $82 \%$. Table 5 shows that the droplet drift was within $8 \mathrm{~m}$ from the sprayed area. On the Petri dishes that were placed 9-20 $\mathrm{m}$ from the sprayed areas, the droplet drift was negligible. 
Pruetthichat Punyawattoe et al

Table-5. Average droplet drift from sprayed area using the four spraying techniques in different evaluation zones

\begin{tabular}{|c|c|c|c|c|c|c|c|c|c|}
\hline \multicolumn{10}{|c|}{ Average droplet drift $\left(\mu \mathrm{g} / \mathrm{cm}^{2}\right)$ on rice at different stages } \\
\hline $\begin{array}{l}\text { Distance from treatment } \\
(\mathbf{m})\end{array}$ & 1 & 2 & 3 & 4 & 5 & 6 & 7 & 8 & 9-20 \\
\hline \multicolumn{10}{|c|}{ Tillering stage } \\
\hline UH1 & 0.316 & 0.210 & 0.082 & 0.024 & 0.017 & 0.009 & 0.005 & - & - \\
\hline UH2 & 0.305 & 0.176 & 0.096 & 0.021 & 0.014 & 0.008 & 0.004 & - & - \\
\hline MK1 & 0.332 & 0.183 & 0.071 & 0.030 & 0.004 & - & - & - & - \\
\hline MK2 & 0.321 & 0.191 & 0.076 & 0.034 & 0.007 & - & - & - & - \\
\hline \multicolumn{10}{|c|}{ Heading stage } \\
\hline UH1 & 0.303 & 0.182 & 0.099 & 0.039 & 0.026 & 0.016 & 0.006 & 0.002 & - \\
\hline $\mathrm{UH} 2$ & 0.265 & 0.228 & 0.108 & 0.047 & 0.009 & 0.010 & 0.002 & - & - \\
\hline MK1 & 0.254 & 0.191 & 0.057 & 0.012 & 0.003 & - & - & - & - \\
\hline MK2 & 0.269 & 0.180 & 0.062 & 0.024 & 0.004 & - & - & - & - \\
\hline \multicolumn{10}{|c|}{ Flowering stage } \\
\hline UH1 & 0.326 & 0.162 & 0.117 & 0.062 & 0.030 & 0.017 & 0.010 & 0.002 & - \\
\hline UH2 & 0.286 & 0.160 & 0.124 & 0.068 & 0.021 & 0.007 & 0.003 & & - \\
\hline MK1 & 0.262 & 0.184 & 0.047 & 0.014 & 0.002 & - & - & - & - \\
\hline MK2 & 0.260 & 0.169 & 0.043 & 0.017 & 0.003 & - & - & - & - \\
\hline
\end{tabular}

We considered that because of the suitable weather conditions and the vertical spray direction provided by the unmanned helicopter, droplet drift from sprayed area was reduced. This, coupled with the low wind speed of less than $0.3 \mathrm{~m} / \mathrm{s}$, mild ambient temperature of $24{ }^{\circ} \mathrm{C}$, and relative humidity of $82 \%$ - all of which are favorable weather conditions-resulted in droplets spreading not beyond $8 \mathrm{~m}$ outside the targeted area; the distance achieved by the unmanned helicopters was only $3 \mathrm{~m}$ greater than that of the motorized knapsack sprayers. The similar result was described by Kamthonsiriwimol et al. (2020) that spraying drift by using UAV in the paddy field was greater than knapsack sprayer. According to the UAV spraying, the droplet size was smaller than the one of knapsack sprayer. Therefore, the drift ability of UAV spraying was higher than conventional spraying by using knapsack sprayer. These findings correspond to those of Xinyu et al. (2014( and Wang et al. (2017), who found that when spraying with a UAV at a height of 3 $\mathrm{m}$ above the plant with a wind flow speed of less than $1 \mathrm{~m} / \mathrm{s}$, the spread of droplets was only found within 10 $\mathrm{m}$ of the last row where fungicides were sprayed.

\section{Conclusion}

The number of droplet density on target areas and droplet deposition on the bottom position from the unmanned helicopters were higher than those from the motorized knapsack sprayers, which is currently the conventional spraying method in Thailand. Furthermore, the unmanned helicopters effectively reduced droplet losses to the ground with those of the conventional method. The efficacy of the unmanned helicopter was similar or greater than that of the motorized knapsack sprayer. Overall, UAVs displayed improved performance, and their use is a rational strategy for pesticide application in Thailand.

\section{Acknowledgement}

We would like to thank Thai Yamaha Motor Co., Ltd. which kindly provided us with a UAV, a field to conduct the experiment, and helped us in the research. We would also like to thank Mr. Predee Rakngam, Pesticide Application Research Section, Entomology and Zoology Group, Plant Protection Research and 
Development Office, Department of Agriculture for useful information and technical assistance.

Disclaimer: None.

Conflict of Interest: None.

Source of Funding: None.

\section{References}

Derksen RC, Zhu H, Fox RD, Brazee RD and Krause CR, 2007. Coverage and drift produced by air induction and conventional hydraulic nozzles used for orchard application. Trans. ASABE. 50: 14931501.

Ebert TA, Taylor RAJ, Downer RA and Hall FR, 1999. Deposit structure and efficacy of pesticide application. 1: Interactions between deposit size, toxicant concentration and deposit number. Pestic. Sci. 55: 783-792.

Hughes EA, Flores AP, Ramos LM, Zalts A, Glass RC and Montserrat JM, 2008. Potential dermal exposure to deltamethrin and risk assessment for manual sprayers: Influence of crop type. Sci. Total. Environ. 391: 34-40.

Machera K, Kapetanakis E, Charistou A, Goumenaki E and Glass RC, 2002. Evaluation of potential dermal exposure of pesticide spray operators in greenhouses by use of visible tracers. J. Environ. Sci. Health Part B. 37: 113-121.

Matthews GA, Bateman R and Miller P, 2014. Pesticide Application Methods. 4th ed. WileyBlackwell, Chichester, UK.

Ministry of Public Health, 2018. Pesticide poisoning. Annual epidemiological surveillance report, Bangkok, Thailand (in Thai).

Kamthonsiriwimol N, Punyawattoe P, Hunhiang D, Hasegawa H, Pibanthan M and Xiaoyu L, 2020.

Evaluation of the spraying deposition and spraying drift by using Unmanned Aerial Vehicle (UAV) in paddy field, pp. 924-936. In Proceedings, PIM 10th National and 3rd International Conference 2020: Digital Transformation and Globalization 2020 (DTGT), 17 July 2020 Panyapiwat Institute of Management Chaengwatthana Rd., Nonthaburi, Thailand.

Nuyttens D, Braekman P, Windey S and Sonck B, 2009. Potential dermal exposure affected by greenhouse spray application technique. Pest Manage. Sci. 65: 781-790.

Office of Agricultural Economics, 2018. Rice. http://www.oae.go.th/view/1/rice/TH-TH.
Accessed 16 August 2018.

Pergher G, 2001. Recovery rate of tracer dyes used for spray deposit assessment. Trans. ASAE. 44: 787794.

Pojananuwong S, Armeen S, Pamorn P, Suwanathane S, Pechtammaros S and Chueyphan S, 2001. Pesticide application technique for control of rice pests. Biennial report, Division of Entomology and Zoology, Department of Agriculture, Bangkok, Thailand (in Thai).

Pojananuwong S, Wechakit D, Ek-amnuay J, Pechtammaros S, Suwanathane S and Chueyphan S, 1999. Pesticide application technique against pests of rice. Biennial report, Division of Entomology and Zoology Department of Agriculture, Bangkok, Thailand (in Thai).

Qin WC, Xue XY, Zhang SM, Gu W and Wang BK, 2018. Droplet deposition and efficiency of fungicides sprayed with small UAV against wheat powdery mildew. Int. J. Agric. Biol. Eng. 11(2): 27-32.

Rice Department, 2018. Rice Knowledge Bank. http://www.ricethailand.go.th/rkb/disease\%20and $\% 20$ insect/index.php.htm. Accessed: 12 August 2018.

Rincón VJ, Sánchez-Hermosilla J, Páez F, PérezAlonso J and Callejón ÁJ, 2017. Assessment of the influence of working pressure and application rate on pesticide spray application with a hand-held spray gun on greenhouse pepper crops. Crop Prot. 96: 7-13.

Sánchez-Hermosilla J, Rincón VJ, Páez F and Fernández M, 2012. Comparative spray deposits by manually pulled trolley sprayer and a spray gun in greenhouse tomato crops. Crop Prot. 31: 119124.

Thongsakul S, Hongtrakul T, Wechakit D, Sakultiengtrong S, Pamorn P and Lekprasert P, 1999. Study on the amount of pesticides exposure on various parts of applicator's body and surrounding environment. Biennial report, Division of Entomology and Zoology, Department of Agriculture, Bangkok, Thailand (in Thai).

Wang X, He X, Wang C, Wang Z, Li L, Wang S, Bonds J, Herbst A and Wang Z, 2017. Spray drift characteristics of fuel powered single-rotor UAV for plant protection. Trans. ASAE. 33: 117-123.

Wang G, Lan Y, Yuan H, Qi H, Chen P, Ouyang F and Han Y, 2019. Comparison of spray deposition, control efficacy on wheat aphids and working efficiency in the wheat field of the unmanned aerial 


\section{Pruetthichat Punyawattoe et al}

vehicle with boom sprayer and two conventional knapsack sprayers. Appl. Sci. 9: 218.

Wechakit D, Ek-amnuay J and Punyawattoe P, 2009. Pesticide application technology handbook. Entomology and Zoology Group, Plant Protection Research and Development Office, Department of Agriculture, Bangkok, Thailand (in Thai).

Wicke H, Backer G and Frießleben R, 1999. Comparison of spray operator exposure during orchard spraying with hand-held equipment fitted with standard and air injector nozzles. Crop Prot. 18: 509-516

Xinyu X, Kang T, Weicai Q, Yubin L and Huihui Z, 2014. Drift and deposition of ultra-low altitude and low volume application in paddy field. Int. J. Agric. Biol. Eng. 7: 23-28.

Xue X, Liang J and Fu XM, 2008. Prospect of aviation plant protection in China. Chin. Agric. Mech. 5: 72-74.
Xue X, Lan Y, Sun Z, Chang C and Hoffmann WC, 2016. Develop an unmanned aerial vehicle based automatic aerial spraying system. Comput. Electron. Agric. 128: 58-66.

\section{Contribution of Authors}

Punyawattoe P: Conceptualized part of the research, performed the experiment, data collection, analysis and manuscript write up

Sutjaritthammajariyangkun $\mathrm{W}$, Thirawut $\mathrm{S}$, Chaiyasing N, Supornsin S \& Sampaothong S: Performed data analysis, and helped in writing and editing of manuscript

Nagura T: Helped in final editing of manuscript 